\title{
Physicochemical and Bacteriological Quality of Groundwater, East of Nile Delta of Egypt
}

\author{
Muhammad Gomaah ${ }^{1 *}$, Amany Ramadan ${ }^{1}$, Mona M. El-Shazly ${ }^{2}$, Yasser A. M. Abdulhady ${ }^{1}$, \\ H. A. Shawky 1 \\ ${ }^{1}$ Department of Hydrogeochemistry, Desert Research Center, Cairo, Egypt \\ ${ }^{2}$ Department of Soil Fertility and Microbiology, Desert Research Center, Cairo, Egypt \\ Email: ^muhammad-gomaah@yahoo.com
}

How to cite this paper: Gomaah, M., Ramadan, A., \& El-Shazly, M. M. (2021). Physicochemical and Bacteriological Quality of Groundwater, East of Nile Delta of Egypt. Journal of Geoscience and Environment Protection, 9, 97-106.

https://doi.org/10.4236/gep.2021.91008

Received: December 21, 2020

Accepted: January 26, 2021

Published: January 29, 2021

Copyright $\odot 2021$ by author(s) and Scientific Research Publishing Inc. This work is licensed under the Creative Commons Attribution International License (CC BY 4.0).

http://creativecommons.org/licenses/by/4.0/

\begin{abstract}
Groundwater is an important source of freshwater for drinking and irrigation purposes, and hence protecting it against depletion and deterioration is extremely required. Groundwater could get contaminated physically, chemically, or microbiologically. Each type of contamination is linked to different sources and in turn imposes different types of health problems and consequences. A water sample from Bahr Al-Baqar Wastewater drain and 13 groundwater samples were collected for physiochemical and bacteriological analyses to evaluate groundwater contamination in As-Salihiyyah and adjacent areas, east of Nile Delta of Egypt. Nitrate, COD, and BOD values collected from Bahr Al-Baqr drain and groundwater exceeded the Egyptian maximum permissible limit for drinking water $(0.5,6,10$, respectively). The total number of viable microorganisms (TVC) test for Bahr Al-Baqar drain was recorded as more than $300 \mathrm{CFU} / \mathrm{mL}$, and the total coliform recorded $1100 \mathrm{MPN} / 100 \mathrm{ml}$, indicating high level of contamination. The high count of the TVC (16- 300 $\mathrm{CFU} / \mathrm{mL}$ ) for groundwater and the total coliform (3 - $1100 \mathrm{MPN} / 100 \mathrm{ml})$ indicated that groundwater is contaminated and unsafe for drinking and might be affected by Bahr Al-Baqar wastewater drain.
\end{abstract}

\section{Keywords}

East of Nile Delta, Bahr Al-Baqar, Groundwater Contamination

\section{Introduction}

Egypt has been facing water scarcity threats due to the steady increase of population in addition to limited water resources. The steady increase of population along with intensified industrial and agricultural activities, large amounts of untreated urban municipal, industrial wastewater and rural domestic wastes are 
discharged into the river Nile, canals or agricultural drains which become an easy dumping site for all kinds of wastes, causing it to become unsafe and unfit for human use. Wastewater discharging is a source of many categories of contaminants to groundwater, including bacteria, viruses, trace elements, and organic compounds which threatens public health. The drainage systems of the Eastern Nile Delta, except for a few drainages, drain to Lake Manzala, which consequently discharges freely into the Mediterranean Sea (Figure 1). Bahr El-Baqar is one of these drainage systems which start near Zagazig city where it collects the wastewater effluents from two secondary drains: the Bilbeis Drain and the Qalubeya Drain.

Several authors studied the groundwater contamination in the area east to the Nile Delta of Egypt, among them; Taha et al. (2004) who investigated sources of Pollution to groundwater and the related environmental impacts in the new communities southeast Nile Delta; Mustafa et al. (2019) investigated groundwater pollution close to Bahr Al-Baqar drain, and used geochemistry and stable isotopes $\left(\delta{ }^{18} \mathrm{O}, \delta{ }^{2} \mathrm{H}\right.$ and $\left.\delta{ }^{15} \mathrm{~N}\right)$ which indicated that sewage disposal, mineral fertilizer, and open drains are the main sources of groundwater contamination; Yousra et al. (2020) evaluated the contamination of groundwater and Prepared

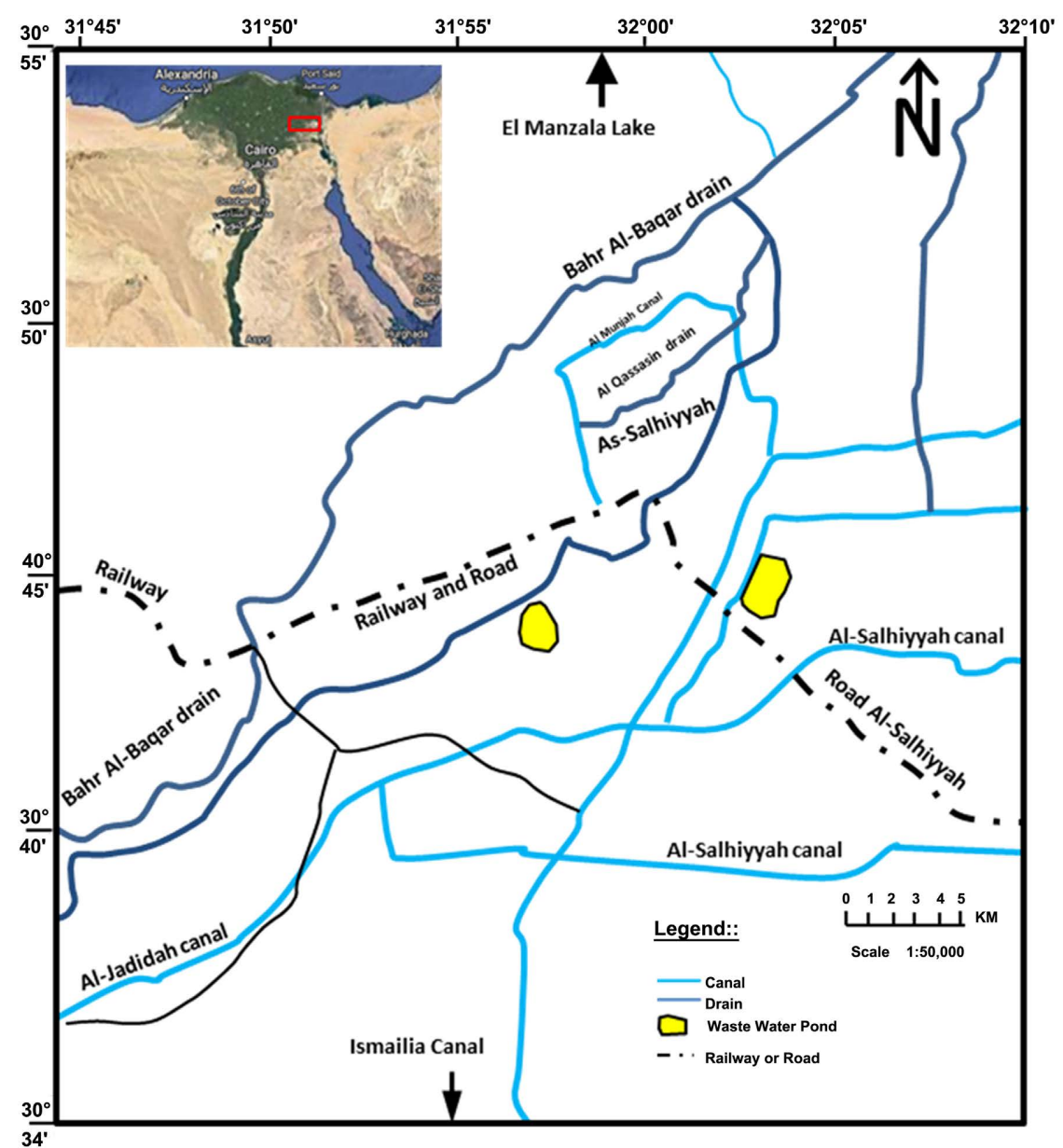

Figure 1. Bahr El-Baqar drain system in the study area. 
silicomolybdate for the removal of heavy metals from the contaminated surface and groundwater in Husseiniyyah area, east of Nile Delta. However, none of these literature evaluated groundwater for contamination according to the bacteriological parameters which will be used here in the current study as prime indicators along with the physiochemical and biological parameters.

\section{Site Description}

Bahr El-Baqar drain transports the water from Zagazig city for about $100 \mathrm{~km}$ to the Ginka sub-basin in the southeast sector of the Lake Manzala. Bahr El-Baqar drain system passes through the Qalubeya, Sharkia and Ismailia Governorates. One secondary drain called Bilbeis Drain starts near Cairo and has a total length of about 60 kilometres. All sewage and industrial wastewater, treated or untreated, from the eastern zone of Greater Cairo is dumped into this drain. The other called Qalubeya Drain is about $70 \mathrm{~km}$ long and runs parallel to the Bilbeis Drain at a distance of about 20 kilometres. It collects treated and untreated wastewater from the critical area of Sohbra El-Khemma and its large industrial area and the urban communities of the Qalubeya and Sharkia Governorates. Both drains are more like open sewers than like agricultural drains. The investigated area is to located to the East of Nile Delta, and close to As-Salhiyyah village and surroundings where Bahr Al-Baqar drain runs through (Figure 1). The main groundwater aquifer in this area is the Quaternary aquifer which is composed mainly of Aeolian and old deltaic deposits.

\section{Materials \& Methods}

A Field trip carried out within July 2018, during which surface water and groundwater samples were manually and aseptically collected from the study area (Figure 2). Fourteen water samples corresponding to all available water sources included surface water (1 sample) and groundwater (13 wells) were collected in sanitized plastic containers for chemical and biological as well as bacteriological analyses. The samples were analyzed using standard methods of analysis of water and wastewater (American Public Health Association, 1995). The collected samples were separated into three aliquots. One of these was acidified with nitric acid (1\%) and stored in cleaned bottles for the measurements of trace elements and soluble heavy metals. The second aliquot was taken in special container $(100 \mathrm{ml})$ for the measurements of biochemical oxygen demands (BOD), chemical oxygen demands (COD) and total organic carbon (TOC). Finally, the third aliquot was collected in a special antiseptic container $(100 \mathrm{ml})$ for the measurements of microbiological and pathological analyses of water. These water samples were immediately kept in the dark, cooled in an insulated container and transported to the laboratory within $10 \mathrm{~h}$. and stored at $4^{\circ} \mathrm{C}$ until bacteriological investigation was finished within $24 \mathrm{~h}$. of collection as specified in standard national and worldwide strategies.

Two kinds of measurements were carried out, field and laboratory, as follow: 


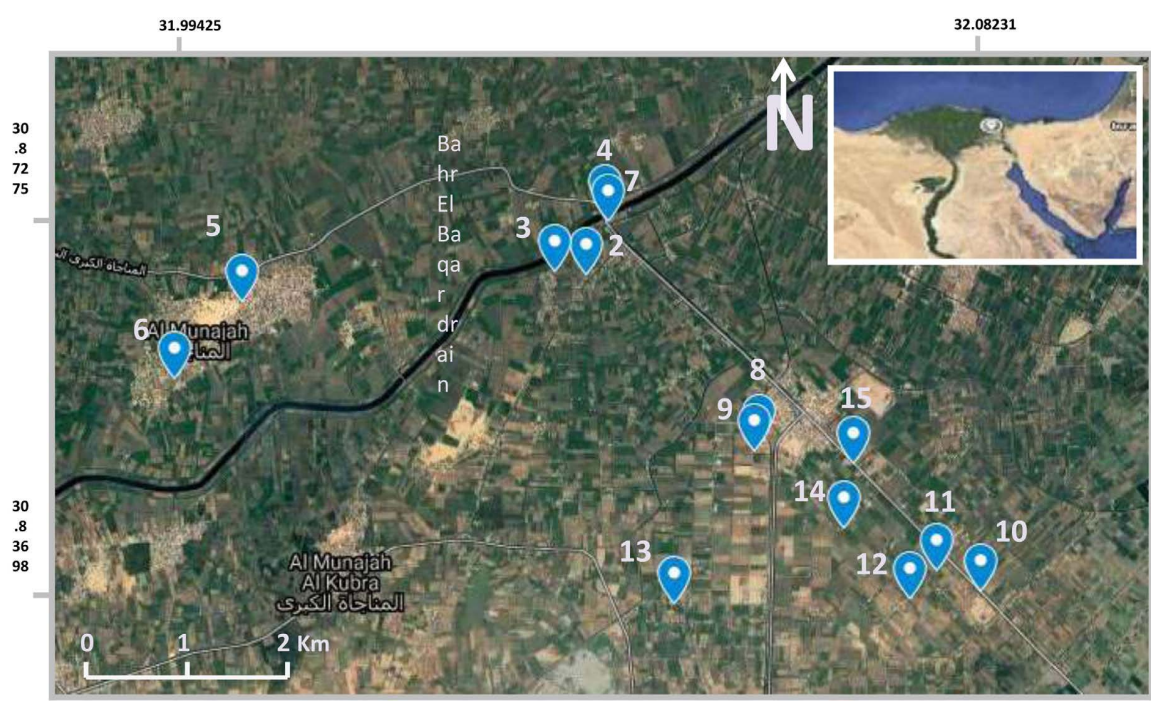

Figure 2. Location map of sampling sites.

\subsection{Field Measurement}

In situ measurements for water samples were done as locations (latitudes and longitudes) using GPS instrument model (Magellan Nave 5000 pro.) together with some physical and chemical characteristics as EC in $\mu \mathrm{S} / \mathrm{cm}$ using Electrical Conductivity meter (Jenway, model 470 ). The $\mathrm{pH}$ was measured by $\mathrm{pH}$ meter (Jenway, model 3150).

\subsection{Laboratory Analyses}

\subsubsection{Chemical Analyses}

Collected water samples have been analyzed for the major and minor dissolved chemical constituents (TDS, $\mathrm{Ca}^{2+}, \mathrm{Mg}^{2+}, \mathrm{Na}^{+}, \mathrm{K}^{+}, \mathrm{CO}_{3}^{2-}, \mathrm{HCO}_{3}^{-}, \mathrm{SO}_{4}^{2-}, \mathrm{Cl}^{-}$, $\mathrm{Br}^{-}, \mathrm{NH}_{3}, \mathrm{NH}_{4}, \mathrm{COD}$ and TOC). The laboratory measurements were carried out by the EC meter (Orion model 150A+), pH meter (Jenway model 3510), flame photometer (Jenway model PFP7), ion-selectivity meter (Orion model 940) and uv/visible spectrophotometer (Thermo-Spectronic model 300). All the analyses were conducted in the central lab., Desert Research Center (DRC), Egypt, following the methods of Rainwater and Thatcher (1964), Fishman, Friedman and Geological (1985), APHA (1998) and ASTM (2002).

Calcium $\left(\mathrm{Ca}^{2+}\right)$ and magnesium $\left(\mathrm{Mg}^{2+}\right.$ were determined titrimetrically using standard EDTA, chloride $\left(\mathrm{Cl}^{-}\right)$by standard $\mathrm{AgNO}_{3}$ titration, bicarbonate $\left(\mathrm{HCO}_{3}^{-}\right.$) by titration with $\mathrm{HCl}$, Biochemical oxygen demand (BOD), chemical oxygen demand (COD) and (TOC )Total organic carbon were analyzed according to (American Society for \& Materials, 2002).

\subsubsection{Bacterial Analyses}

Water samples were kept at $22^{\circ} \mathrm{C}$ and $37^{\circ} \mathrm{C}$, and the total viable bacterial counts (TVBCs) were determined using the spread-plate method (APHA, 1998). The number of total and fecal coliforms was determined using the most probable number (MPN) method using MacConkey broth media. The positive tubes were 
streaked on the Eosin Methylene Blue (EMB) agar plates. Microscopic examination was carried out to ensure gram-negative, non-spore forming rods (APHA, 1998). MPN of fecal streptococci was determined using azide dextrose broth at $37^{\circ} \mathrm{C}$ for $48 \mathrm{hr}$. Positive tubes were indicated by dense turbidity and confirmed using ethyl violet azide dextrose broth incubated at $37^{\circ} \mathrm{C}$ for $24 \mathrm{hr}$ (APHA, 1998). The isolation of gram-negative bacteria for groundwater samples in the study area were performed using MacConkey agar supplemented with $0.001 \mathrm{~g} / \mathrm{L}$ crystal violet (Hosty, 1971). Several isolates were purified, screened and the suspected similar ones were grouped for the purpose of selection and identification processes. Isolates from the examined water samples were subjected to identification by biochemical characteristics using API 20E strip system (BioMereux). Each API 20E strip consists of fifteen water points containing dehydrated media. The isolate to be tested was suspended in sterile saline and added to each water sample. The inoculated strip was incubated for $16-24 \mathrm{~h}$ and the color reactions were noted either positive or negative.

\section{Results \& Discussion}

\subsection{Inorganic, Biological, and Bacteriological Parameters}

According to Table 1, the values of ammonia, BOD5, and COD collected from Bahr Al-Baqr drain exceeded the Egyptian maximum permissible limit for drinking water $(0.5,6,10$, respectively), while the values of nitrate and TOC did not exceed the maximum permissible limit $(45,10$, respectively). The total viable

Table 1. Concentrations of inorganic \& biological constituents in the water resources samples within the study area $(\mathrm{mg} / \mathrm{l})$.

\begin{tabular}{cccccc}
\hline Sample No. & $\mathrm{NO}_{3}^{-}(\mathrm{mg} / \mathrm{l})$ & $\mathrm{NH}_{4}^{+}(\mathrm{mg} / \mathrm{l})$ & BOD5 & COD & TOC\% \\
\hline 2 & 9.8 & 1.4 & 121.2 & 66.7 & Nil \\
3 & 22.4 & 1.4 & 115.2 & 100 & 0.009 \\
4 (Bahar Al-Baqar) & 29.4 & 14 & 205.2 & 100 & 0.02 \\
5 & 33.6 & 4.2 & 205.2 & 133.3 & 0.006 \\
6 & 42 & 1.4 & 169.8 & 133.3 & 0.007 \\
7 & 29.4 & 4.2 & 145.2 & $\mathrm{Nil}$ & 0.006 \\
8 & 15.4 & 4.2 & 133.8 & 66.7 & 0.006 \\
9 & 18.2 & 2.8 & - & $\mathrm{Nil}$ & 0.017 \\
10 & 19.6 & 1.4 & - & 133.3 & 0.009 \\
11 & 11.2 & 1.4 & - & 166.7 & 0.015 \\
12 & 8.4 & 7 & 18 & 166.7 & 0.011 \\
13 & 1.4 & 2.8 & - & 133.3 & 0.009 \\
14 & $\mathrm{Nil}$ & 1.4 & - & 133.3 & 0.011 \\
15 & $\mathrm{Nil}$ & 11.2 & - & 133.3 & 0.009 \\
Permissible levels & 45 & 0.5 & 6 & 10 & 10 \\
\hline & & & & &
\end{tabular}


count (TVC) is a test that is used to estimate the total numbers of live microorganisms that are capable of growing into distinct colonies, such as bacteria, yeast or mould species, that are present in a water sample. The results of the TVC test give an indication of the general level of contamination $(>50 \mathrm{CFU} / \mathrm{mL})$ in a system and the overall quality of the water. The result of the TVC test for Bahr Al-Baqar drain showed high total numbers of live microorganisms ( $\uparrow 300$ $\mathrm{CFU} / \mathrm{mL}$ ) which indicates high level of contamination. In addition, the presence of the total coliforms, thermotolerant coliforms, E. coli and Enterococcus spp. indicates that the water may be contaminated by human or animal wastes (ICMSF, 1998). The number of total coliform for the collected sample from Bahr Al-Baqar drain was $1100 \mathrm{MPN} / 100 \mathrm{ml}$, while the triple sugar iron (TSI) detected the presence of Klebsiella. Pneumonia, indicating anthropogenic contamination.

The values of nitrate for all groundwater samples were under the maximum permissible limit $(45 \mathrm{mg} / \mathrm{l})$, while the values of ammonia ranged between 1.4 to $14 \mathrm{mg} / \mathrm{l}$, exceeding the maximum permissible limit $(0.5 \mathrm{mg} / \mathrm{l})$. The BOD and COD exceeded the maximum limit for most of the groundwater sample which indicate contamination through leakage from Bahr Al-Baqar drain. The TVC test showed that the minimum total numbers of live microorganisms was recorded in well no. $7(16 \mathrm{CFU} / \mathrm{mL})$, while the maximum total numbers $(\uparrow 300$ $\mathrm{CFU} / \mathrm{mL}$ ) was recorded in wells no. 5, 6, 8, 9, 14, and 15 (Figure 3). The minimum count of the total coliform (3 MPN/100ml) was recorded in wells no. 2, 8 , 11,13 , and 15 , while the maximum count $(1100 \mathrm{MPN} / 100 \mathrm{ml})$ was recorded in wells no. 4, 5, 6, 10, and 12 (Figure 4). The high count of the TVC and the total coliform indicate that groundwater in such area is contaminated and unsafe for drinking according to the Egyptian Drinking Water Quality Standards (2007). In addition to that, the results in Table 2 showed the presence of $E$. coli, Klebsiella. Pneumonia, Salmonella. Typhi, Shigella, Aerobacles. Aeroges, and Bacillus.

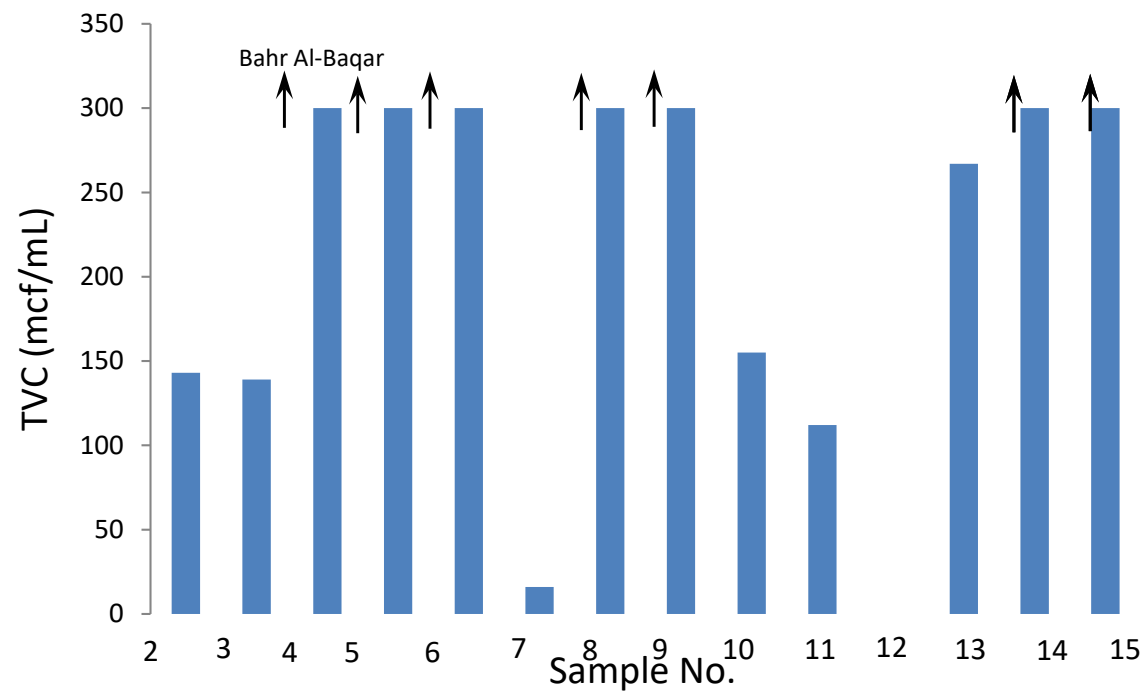

Figure 3. The TVC test $(\mathrm{mcf} / \mathrm{ml})$ showed high total numbers of live microorganisms in most of the samples. 


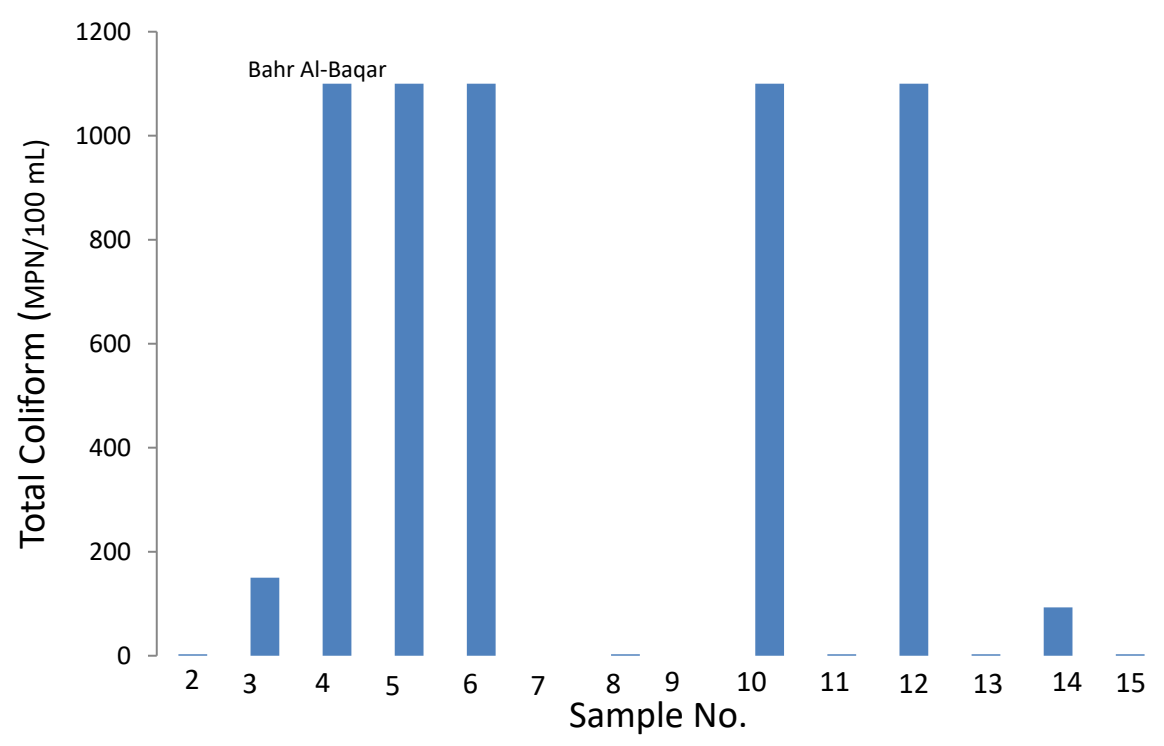

Figure 4. The Total Coliform (MPN/100ml) showed high total count in some of the samples.

Table 2. Results of the Total viable bacteria (cfu/ml), total coliform (MPN/100ml), and TSI.

\begin{tabular}{cccc}
\hline \multirow{2}{*}{ Sample No. } & Total viable bacteria $(\mathrm{cfu} / \mathrm{ml})$ & Total coliform & \multirow{2}{*}{ TSI } \\
\cline { 2 - 3 } 2 & 143 & MPN/100ml & E. coli \\
3 & 139 & 150 & E. coli \\
4 & $\uparrow 300$ & 1100 & Klebsiella pneumoniae \\
5 & $\uparrow 300$ & 1100 & Salmonella typhi \\
6 & $\uparrow 300$ & 1100 & Shigella \\
7 & 16 & - & - \\
8 & $\uparrow 300$ & 3 & Bacillus \\
9 & $\uparrow 300$ & - & Bacillus \\
10 & 155 & 1100 & E. coli \\
11 & 112 & 3 & E. coli \\
12 & $\mathrm{C}$ & 1100 & Aerobacles. Aeroges \\
13 & 267 & 3 & E. coli \\
14 & $\uparrow 300$ & 93 & E. coli \\
15 & $\uparrow 300$ & 3 & E. coli \\
\hline
\end{tabular}

\subsection{Physiochemical Parameters}

The sample collected from Bahr Al-Baqar showed an EC of $1330 \mu \mathrm{S} / \mathrm{cm}$, and a $\mathrm{pH}$ of 7.3 (Table 3). The concentration of $\mathrm{Al}^{3+}$ exceeded the maximum permissible limit $(0.2 \mathrm{mg} / \mathrm{l})$ as shown in Table 4 . The maximum EC value for groundwater was recorded in well no. $7(24,700 \mu \mathrm{S} / \mathrm{cm})$, while the minimum value $(770$ $\mu \mathrm{S} / \mathrm{cm}$ ) was recorded in well no. 2 . According to Table 4 the $\mathrm{Fe}^{3+}$ concentration 
M. Gomaah et al.

Table 3. Chemical characteristics of surface water and groundwater samples of the Quaternary aquifer, East of Nile Delta.

\begin{tabular}{|c|c|c|c|c|c|c|c|c|c|c|c|c|}
\hline No & & $\mathrm{pH}$ & EC & Unit & $\mathrm{Ca}^{2+}$ & $\mathrm{Mg}^{2+}$ & $\mathrm{Na}^{+}$ & $\mathrm{K}^{+}$ & $\mathbf{C O}_{3}^{2-}$ & $\mathrm{HCO}_{3}^{-}$ & $\mathrm{SO}_{4}^{2-}$ & $\mathrm{Cl}^{-}$ \\
\hline 4 & Bahr Al-Baqar drain & 7.3 & 1380 & $\mathrm{mg} / \mathrm{l}$ & 34.54 & 80 & 95 & 15 & Nil & 37.21 & 21.5182 & 65.2 \\
\hline 2 & Groundwater & 7.3 & 770 & $\mathrm{mg} / \mathrm{l}$ & 72 & 43.74 & 50 & 7 & Nil & 21.35 & 17.271 & 60 \\
\hline 3 & Groundwater & 7.4 & 1852 & $\mathrm{mg} / 1$ & 34.02 & 112 & 173 & 12 & Nil & 35.38 & 16.7729 & 45.12 \\
\hline 5 & Groundwater & 7.3 & 6500 & $\mathrm{mg} / \mathrm{l}$ & 168 & 102.06 & 1060 & 15 & Nil & 57.95 & 70.6803 & 156.347 \\
\hline 6 & Groundwater & 7.4 & 2330 & $\mathrm{mg} / 1$ & 104 & 72.9 & 235 & 61 & Nil & 41.48 & 23.6195 & 57.32 \\
\hline 7 & Groundwater & 7.1 & 24,700 & $\mathrm{mg} / \mathrm{l}$ & 952 & 699.44 & 3300 & 80 & Nil & 26.23 & 984.62 & 8012 \\
\hline 8 & Groundwater & 7 & 2010 & $\mathrm{mg} / 1$ & 88 & 48.6 & 160 & 19 & Nil & 43.31 & 235.21 & 350 \\
\hline 9 & Groundwater & 7.3 & 1795 & $\mathrm{mg} / \mathrm{l}$ & 96 & 58.32 & 165 & 12 & Nil & 34.77 & 167.612 & 428 \\
\hline 10 & Groundwater & 7.4 & 2280 & $\mathrm{mg} / \mathrm{l}$ & 160 & 24.3 & 210 & 17 & Nil & 39.65 & 218.444 & 513.2 \\
\hline 11 & Groundwater & 7.2 & 1945 & $\mathrm{mg} / 1$ & 168 & 53.46 & 180 & 29 & Nil & 67.71 & 346.615 & 515.817 \\
\hline 12 & Groundwater & 7.2 & 1722 & $\mathrm{mg} / 1$ & 88 & 78 & 130 & 11 & Nil & 37.82 & 615.134 & 231.2 \\
\hline 13 & Groundwater & 7.3 & 1677 & $\mathrm{mg} / \mathrm{l}$ & 96 & 43.74 & 150 & 15 & Nil & 38.43 & 556.368 & 180 \\
\hline 14 & Groundwater & 7.2 & 3100 & $\mathrm{mg} / 1$ & 176 & 82.62 & 370 & 13 & Nil & 63.44 & 405.109 & 750 \\
\hline 15 & Groundwater & 7.1 & 2540 & $\mathrm{mg} / 1$ & 136 & 38.88 & 283 & 20 & Nil & 54.29 & 371.708 & 543.2 \\
\hline
\end{tabular}

Table 4. Concentrations of the inorganic constituents in the water resources samples within the study area (mg/l).

\begin{tabular}{|c|c|c|c|c|c|c|c|c|c|c|}
\hline Sample No. & $\mathrm{Al}^{3+}$ & $\mathrm{Fe}^{3+}$ & $\mathrm{Cr}$ & $\mathrm{Mn}^{2+}$ & $\mathrm{Cu}^{2+}$ & $\mathrm{Pb}^{2+}$ & $\mathrm{Mo}^{2+}$ & $\mathrm{Zn}^{2+}$ & $\mathrm{B}^{3+}$ & $\mathrm{Ni}^{3+}$ \\
\hline \multicolumn{11}{|c|}{ Surface water } \\
\hline 4 & 0.5075 & 1.888 & 0.0037 & 0.2359 & Nil & 0.0094 & 0.0012 & 0.021 & Nil & 0.0031 \\
\hline \multicolumn{11}{|c|}{ Groundwater } \\
\hline 2 & 0.3236 & 0.156 & Nil & 0.1038 & Nil & 0.00029 & 0.002 & 0.172 & Nil & 0.0046 \\
\hline 3 & Nil & Nil & 0.0034 & 0.1523 & Nil & 0.0443 & 0.0042 & Nil & Nil & 0.0027 \\
\hline 5 & Nil & Nil & 0.0422 & 0.3193 & Nil & Nil & 0.0228 & 0.142 & 0.8242 & 0.0014 \\
\hline 6 & Nil & 0.138 & 0.007 & 0.0661 & Nil & Nil & 0.0256 & 0.017 & 0.137 & Nil \\
\hline 7 & Nil & 1.639 & 0.0186 & 2.212 & Nil & Nil & 0.0002 & 0.0048 & 1.133 & Nil \\
\hline 8 & 0.21 & 6.119 & 0.0107 & 1.857 & 0.0057 & Nil & 0.003 & Nil & Nil & 0.0028 \\
\hline 9 & Nil & Nil & 0.0102 & 0.4344 & Nil & Nil & 0.0019 & Nil & Nil & 0.11 \\
\hline 10 & Nil & 0.1448 & 0.0072 & 0.3626 & Nil & Nil & 0.0045 & Nil & Nil & 0.0038 \\
\hline 11 & 0.0471 & 0.936 & 0.0073 & 2.116 & 0.0202 & Nil & 0.17 & Nil & 0.0348 & 0.274 \\
\hline 12 & 0.2138 & 0.534 & 0.004 & 0.572 & Nil & Nil & 0.0033 & 0.0014 & Nil & 0.0035 \\
\hline 13 & Nil & 0.0037 & 0.007 & 0.8175 & Nil & Nil & 0.0014 & Nil & Nil & 0.0036 \\
\hline 14 & Nil & 0.5455 & 0.0073 & 1.653 & Nil & Nil & 0.0077 & Nil & 0.0805 & 0.001 \\
\hline 15 & Nil & 0.3321 & 0.0093 & 0.9412 & Nil & Nil & 0.0106 & Nil & 0.0305 & Nil \\
\hline Permissible levels & 0.2 & 0.3 & 0.001 & 0.4 & 2 & 0.01 & 0.07 & 5 & 0.5 & 0.2 \\
\hline
\end{tabular}

exceeded the maximum permissible limit $(0.3 \mathrm{mg} / \mathrm{l})$ in wells no. $7,8,11,12,14$, and 15. Cr exceeded the maximum limit $(0.001 \mathrm{mg} / \mathrm{l})$ in most of groundwater 
samples, while $\mathrm{Pb}^{2+}, \mathrm{Mo}^{2+}$ and $\mathrm{B}^{3+}$ exceeded the permissible limits in wells no, 3, 11 , and 5, 7 respectively.

\section{Conclusion}

According to the obtained results, it could be concluded that, Nitrate, COD, and BOD values collected from Bahr Al-Baqr drain and groundwater exceeded the Egyptian maximum permissible limit for drinking water $(0.5,6,10$, respectively). The total number of viable microorganisms (TVC) test for Bahr Al-Baqar drain was recorded as more than $300 \mathrm{CFU} / \mathrm{mL}$, and the total coliform recorded 1100 MPN/100ml, indicating high level of contamination. On the other hand, the high count of the TVC for groundwater $(16-\uparrow 300 \mathrm{CFU} / \mathrm{mL})$ and the total coliform (3 - $1100 \mathrm{MPN} / 100 \mathrm{ml}$ ) indicated that groundwater is unsafe for drinking and reflects leakage from the contaminated Bahr Al-Baqar wastewater drain and the agriculture activities.

\section{Conflicts of Interest}

The authors declare no conflicts of interest regarding the publication of this paper.

\section{References}

American Public Health Association (1995). Standard Methods for the Examination of Water and Wastewater (Vol. 21). Washington DC, WA: American Public Health Association.

American Society for Testing and Materials (ASTM) (2002). Water and Environmental Technology. Annual Book of ASTM Standards, Section 11: 11.01 and 11.02, West Conshohocken.

American Society for, \& Materials (2002). Annual Book of ASTM Standards 2002. West Conshohocken, PA: American Technical.

APHA (American Public Health Association) (1998). Standard Methods for the Examination of Water and Wastewaters (21st ed.). Washington DC.

EWQS (Egyptian Drinking Water Quality Standards) (2007). Ministry of Health, Population Decision Number 458.

Fishman, M. J., Friedman, L. C., \& Geological Survey (U.S.) (1985). Methods for Determination of Inorganic Substances in Water and Fluvial Sediments. Geological Survey, Denver: U.S. Dept. of the Interior. https://doi.org/10.3133/ofr85495

Hosty, T. S. (1971). Diagnostic Procedures for Bacterial, Mycotic and Parasitic Infections (5th ed.). American Journal of Public Health, 61, 206.

https://doi.org/10.2105/AJPH.61.1.206-a

ICMSF (International Commission on Micro-biological Specifications for Foods) (1998). Microorganisms in Foods (pp. 461-472). Suffolk, MA: St Edmunds Bury Press.

Mustafa, E., Ali, E. Z. M., \& Stash, O. S. (2019). Hydrochemical and Stable Isotopes Indicators for Detecting Sources of Groundwater Contamination Close to Bahr El-Baqar drain, eastern Nile Delta, Egypt. Water Science, 33, 54-64.

https://doi.org/10.1080/11104929.2019.1635346

Rainwater, F. H., \& Thatcher, L. L. (1964). Methods for Collection and Analysis of Water 
Samples. Water-Supply Paper 1454, Washington DC: U.S. Govt. Print. Off., Geological Survey.

Taha, A. A., Mahmoudi, A. E. S. E., \& El-Haddad, I. M. (2004). Pollution Sources and Related Environmental Impacts in the New Communities Southeast Nile Delta. Egypt Emirates Journal for Engineering Research, 9, 35-49.

Yousra, H. K., Mohamed, E. A. A., Muhammad, G., \& Hesham, A. E. (2020). Preparation and Characterization of Manganese Silicomolybdate for the Adsorptive Removal of $\mathrm{Pb}(\mathrm{II})$ and $\mathrm{Fe}(\mathrm{III})$ Metal Ions from Aqueous Medium: Case Study: Hesinia Area, Egypt. Desalination and Water Treatment, 193, 95-105. 